\title{
Seasonal and hydrologic drivers of dissolved organic matter and nutrients in the upper Kuparuk River, Alaskan Arctic
}

\author{
Amy Townsend-Small $\cdot$ James W. McClelland • \\ R. Max Holmes • Bruce J. Peterson
}

Received: 29 October 2009/Accepted: 12 April 2010/Published online: 9 May 2010

(C) The Author(s) 2010. This article is published with open access at Springerlink.com

\begin{abstract}
As the planet warms, widespread changes in Arctic hydrology and biogeochemistry have been documented and these changes are expected to accelerate in the future. Improved understanding of the behavior of water-borne constituents in Arctic rivers with varying hydrologic conditions, including seasonal variations in discharge-concentration relationships, will improve our ability to anticipate future changes in biogeochemical budgets due to changing hydrology. We studied the relationship between seasonal water discharge and dissolved organic carbon and nitrogen (DOC and DON) and nutrient concentrations in the upper Kuparuk River, Arctic Alaska. Fluxes of most constituents were highest during initial snowmelt runoff in spring, indicating that this historically under-studied period contributes significantly to total
\end{abstract}

A. Townsend-Small ( $\square)$

Department of Earth System Science, University

of California Irvine, Irvine, CA 92697, USA

e-mail: atownsen@uci.edu

\section{J. W. McClelland}

Marine Science Institute, The University of Texas

at Austin, Port Aransas, TX 78373, USA

R. Max Holmes

The Woods Hole Research Center, Woods Hole, MA 02540, USA

\section{B. J. Peterson}

Marine Biological Laboratory, The Ecosystems Center, Woods Hole, MA 02543, USA annual export. In particular, the initial snowmelt period (the stream is completely frozen during the winter) accounted for upwards of $35 \%$ of total export of DOC and DON estimated for the entire study period. DOC and DON concentrations were positively correlated with discharge whereas nitrate $\left(\mathrm{NO}_{3}{ }^{-}\right)$and silicate were negatively correlated with discharge throughout the study. However, discharge-specific DOC and DON concentrations (i.e. concentrations compared at the same discharge level) decreased over the summer whereas discharge-specific concentrations of $\mathrm{NO}_{3}{ }^{-}$ and silicate increased. Soluble reactive phosphorus (SRP) and ammonium $\left(\mathrm{NH}_{4}{ }^{+}\right)$were negatively correlated with discharge during the spring thaw, but were less predictable with respect to discharge thereafter. These data provide valuable information on how Arctic watershed biogeochemistry will be affected by future changes in temperature, snowfall, and rainfall in the Arctic. In particular, our results add to a growing body of research showing that nutrient export per unit of stream discharge, particularly $\mathrm{NO}_{3}{ }^{-}$, is increasing in the Arctic.

Keywords Arctic - Stream - Headwaters · Carbon $\cdot$ Nitrogen $\cdot$ Nutrients

\section{Introduction}

The Arctic freshwater system has changed dramatically over recent decades, and changes are expected 
to accelerate in the future (Chapin et al. 2000; Rouse et al. 1997; Arctic Climate Impact Assessment 2005; Anisimov et al. 2007; White et al. 2007). For example, river discharge to the Arctic Ocean has increased (Peterson et al. 2002; McClelland et al. 2006), and climate models suggest that enhanced net precipitation over the pan-Arctic watershed under warmer conditions will support greater increases in continental runoff over the twenty-first century (Holland et al. 2006, 2007; Meehl et al. 2006; Francis et al. 2009). Interannual variability, sparse precipitation datasets at high latitudes, and challenges associated with quantifying winter precipitation have made it difficult to diagnose the exact causes of changes in Arctic river discharge to date (Rawlins et al. 2009). However, tight linkages between hydrology and biogeochemistry in watersheds (Creed et al. 1996; Creed and Band 1998; Burns 2005; Hinzman et al. 1991; Steiglitz et al. 2000, 2003) make changes in the export of river-borne materials inevitable as river discharge increases. Export of inorganic nutrients (N, P, Si) and DOC and DON are of particular interest because they serve as important resources for downstream ecosystems (Amon and Meon 2004; Post et al. 2009).

Relationships between hydrology and biogeochemistry in Arctic watersheds have been demonstrated in a variety of studies (e.g., Peterson et al. 1986, 1992; McNamara et al. 2008). A significant proportion of primary production in Arctic ecosystems is exported as dissolved and particulate organic $\mathrm{C}$ in rivers (McGuire et al. 2009), and mobilization of terrestrial nutrients during high-discharge events drives productivity in oligotrophic lakes and streams (Hobbie et al. 1999; MacIntyre et al. 2006). Constituent concentrations in Arctic streams vary with changing discharge due to snowmelt and/or rainfall as observed in many other places around the world. However, relationships between discharge and constituent concentrations are also strongly influenced by freeze-thaw dynamics and permafrost heterogeneity across the Arctic landscape (Giblin et al. 1991; McNamara et al. 1997; Shaver et al. 2006). As permafrost degrades, changes in $C$ and $\mathrm{N}$ export via rivers may result from changes in water flow paths through soils and/or microbial activity (Frey and McClelland 2009). Some studies predict that changes in Arctic hydrology will result in greater riverine export of terrestrial OM due to thawing of organic-rich permafrost (Frey and Smith 2005). Other studies suggest that $\mathrm{OM}$ export will decrease as permafrost thaws and water flow paths deepen (e.g., Striegl et al. 2005, 2007; Petrone et al. 2006, 2007), either because dissolved OM is trapped in newlythawed mineral soils or respired during longer residence times. At the same time, increased water flow through mineral soils (as opposed to organic rich soils) and increased net $\mathrm{N}$ mineralization under warmer conditions may increase hydrologic export of inorganic N (Shaver et al. 1992; Jones et al. 2005; Greenwald et al. 2008). In fact, one assessment concluded that riverine nutrient input to the entire coastal Arctic might already be increasing (Dittmar and Kattner 2003), although data are extremely sparse. A recent analysis of a long-term dataset for the Kuparuk River found that nitrate $\left(\mathrm{NO}_{3}{ }^{-}\right)$export has increased in recent years (McClelland et al. 2007), and another study predicted that riverine export of dissolved organic $\mathrm{N}$ and $\mathrm{P}$ may increase by up to $50 \%$ in the next century due to warming in Siberian watersheds (Frey et al. 2007a).

While our understanding of linkages between hydrology and biogeochemistry in Arctic watersheds is improving, logistical challenges associated with working at remote field sites and sampling highly variable flow (including seasonal freeze/thaw dynamics and rain events) make detailed analyses of discharge-constituent relationships in Arctic streams relatively rare (except see Peterson et al. 1986, 1992; McNamara et al. 2008). Tundra streams are of particular interest because they often have very high OM loads. The purpose of our study was to determine the biogeochemical response of variations in stream discharge in the upper Kuparuk River, with particular emphasis on high flow events as well as the brief lowdischarge period when river flow is just beginning in the spring. We hypothesized that changing hydrologic flowpaths and terrestrial biogeochemistry during the summer growing season will be expressed in the relationship of constituents to stream discharge in Arctic rivers at both seasonal and decadal time scales. A few previous studies of nutrient and OM export from the upper Kuparuk River have included similar high-resolution sampling efforts (Peterson et al. 1986, 1992; McNamara et al. 2008). The high-resolution work presented here provides a contemporary point of comparison with the earlier studies (McNamara et al. (2008) present data from the mid-1990s) and offers new insight with respect to co-variations in stream chemistry and river discharge in the Arctic. 
A detailed understanding of how constituent concentrations respond to peaks in discharge due to snowmelt and rain storms will help to predict the biogeochemical implications of changing Arctic hydrology.

\section{Study area}

The upper Kuparuk River is a tundra stream located north of the Brooks Range in Arctic Alaska (Fig. 1), where it drains the foothills free of glacial or deep spring sources (Craig and McCart 1975). The upper Kuparuk is a relatively small stream (average summer discharge $\sim 2.5 \mathrm{~m}^{3} / \mathrm{s}$ ) as compared to the Kuparuk River mouth, where discharge can reach $1000 \mathrm{~m}^{3} / \mathrm{s}$ during the spring flood (Fig. 2a). In larger Arctic rivers, including the Kuparuk River at its mouth, the initial pulse of water associated with the spring melt accounts for the vast majority of total annual discharge. In contrast, peak discharge in small headwater streams, such as the upper Kuparuk, is less predictable. There is a peak in discharge during the spring thaw, but often, large storm events later in the summer produce comparable or even larger peaks in discharge (Kane et al. 2003, 2008).

The upper portion of the Kuparuk has been the subject of a number of studies over the past $\sim 30$ years as a part of the Arctic Long Term Ecological Research Project (LTER). These studies have shown that concentrations of inorganic $\mathrm{N}$ and $\mathrm{P}$ are generally very low as compared to other streams (Peterson et al. 1992; McNamara et al. 2008) and that primary productivity is P limited (Slavik et al. 2004). In-stream $\mathrm{C}$ fixation rates are several orders of magnitude lower than $\mathrm{C}$ inputs from the watershed (Peterson et al. 1986).

We sampled the upper Kuparuk River near the intersection of the Trans-Alaska pipeline and the Dalton Highway $\left(68^{\circ} 38^{\prime} 35^{\prime \prime} \mathrm{N}, 1^{\circ} 49^{\circ} 24^{\prime} 15^{\prime \prime} \mathrm{W}\right.$; Fig. 1). For many years, the Arctic LTER project has been adding phosphate to this section of the Kuparuk to study the effects of fertilization on stream function (Benstead et al. 2007; Slavik et al. 2004; Peterson et al. 1993). Our sampling point was located in the reference reach upstream of the fertilizer addition point. The watershed area represented by this sampling point is $143 \mathrm{~km}^{2}$, compared to a total watershed area of about $8400 \mathrm{~km}^{2}$ measured at the Arctic Ocean.

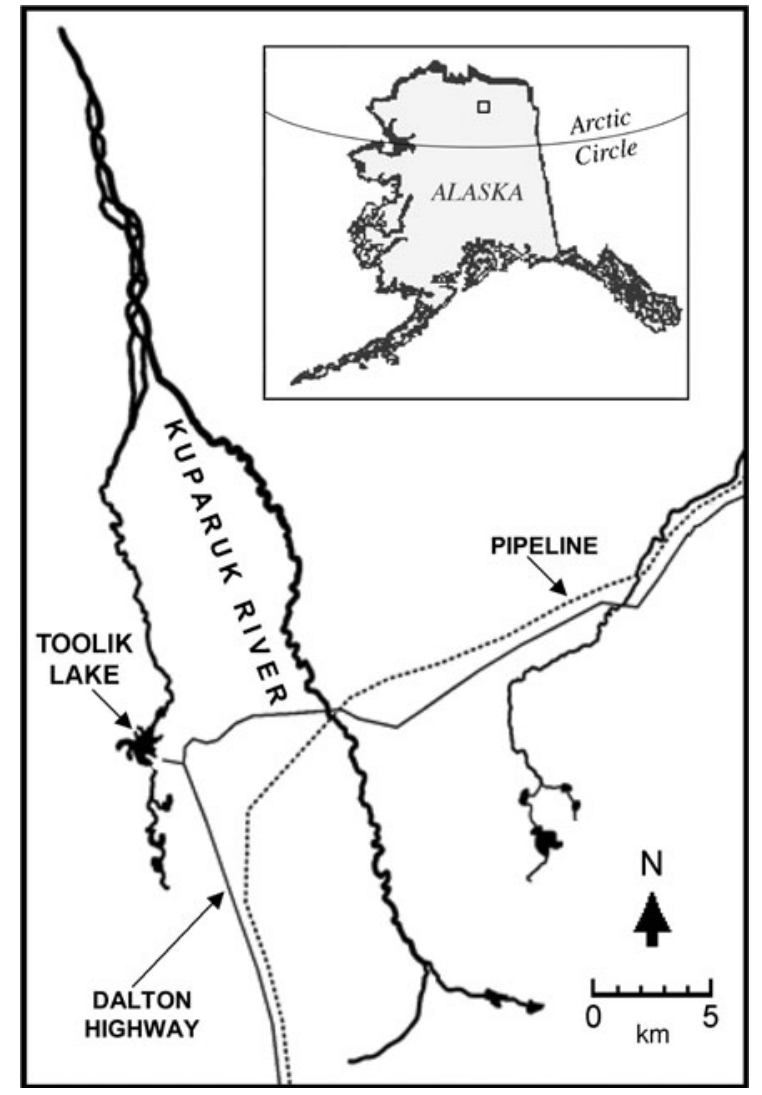

Fig. 1 Map of the study area. Sampling point was slightly upstream of the intersection of the Dalton Highway and the Trans-Alaskan pipeline. Inset shows location within Alaska

\section{Methods}

Stream stage in the upper Kuparuk is measured by a pressure transducer and recorded by a datalogger every $15 \mathrm{~min}$. Water level is related to discharge with a series of rating curves measured throughout the hydrologic year with a two-dimensional Flow Tracker Acoustic Doppler Velocity meter. The stream channel cross section changes throughout the year, especially in spring when the bottom and sides of the stream are often covered in ice. The error of discharge measurements can range from 2 to 20\% (Sauer and Meyer 1992), but since we made frequent measurements of stream depth, width, and flow, during a variety of hydrologic conditions including during snowmelt, we assumed our error to be about $5 \%$. The gauge system is operated and maintained by the University of Alaska Fairbanks Water and Environmental Research Center (Kane and Hinzman 2006). 

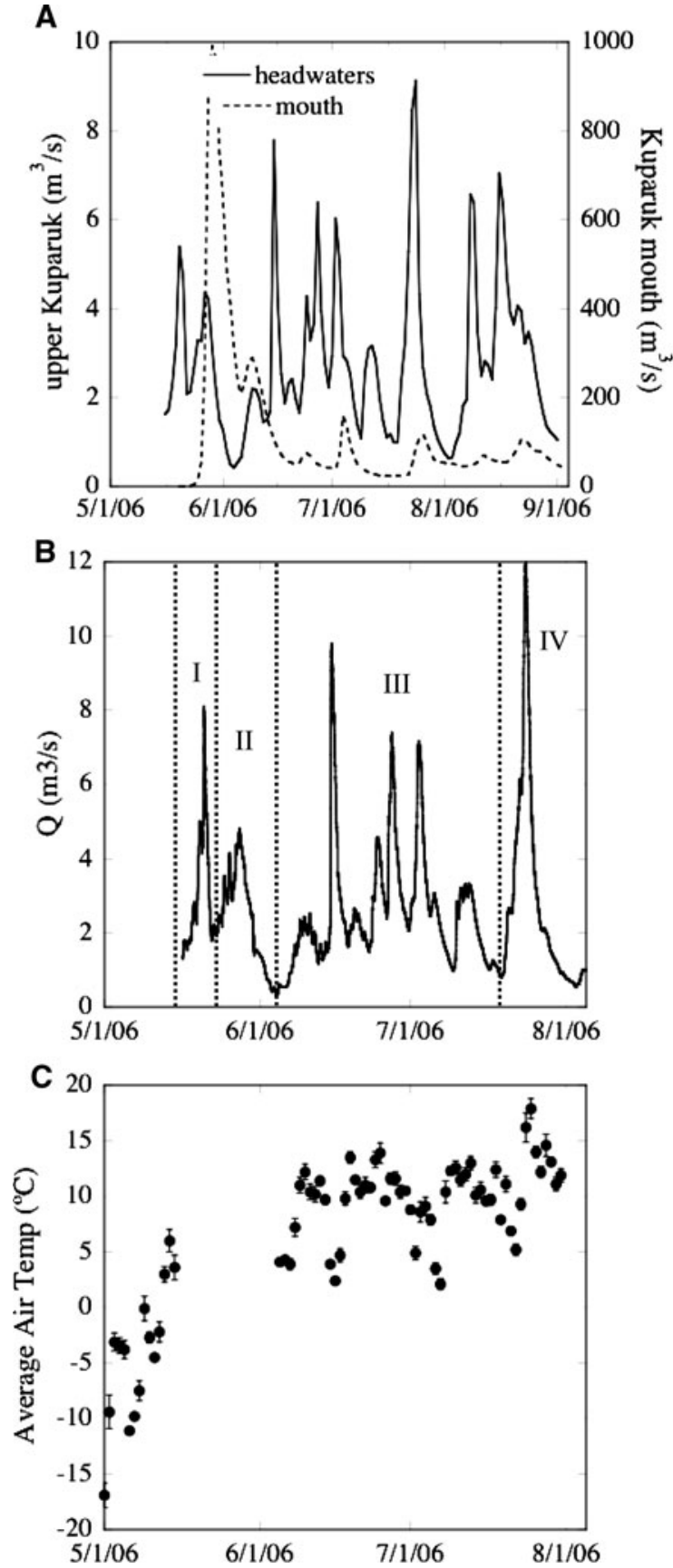

Water samples were collected from May through July of 2006. There was no predetermined sampling schedule for this study; rather, we varied our sampling frequency in order to capture water chemistry dynamics during selected events (3 or more samples per day), with sporadic sampling (1 or 2 samples per week) in the interim. High frequency
4 Fig. 2 River discharge (Q) in the Kuparuk River in springsummer 2006. a average daily discharge for the upper Kuparuk (headwaters) and, for comparison, daily averaged discharge at the river mouth. b discharge in the upper Kuparuk at 15-min resolution. The study period is split into four time periods (I-IV). Time period I (5/15/06-5/24/06) captures the initial snowmelt pulse. Time period II $(5 / 25 / 06-6 / 5 / 06)$ captures a second snowmelt pulse. Time period III (6/6/06-7/18/06) captures several intermediate sized rain events during the middle of the study period. Time period IV (7/19/06-7/26/06) captures the largest rain event of the summer. Stream discharge measurements in the upper Kuparuk began on May 16, 2006. c Average daily air temperature $\left({ }^{\circ} \mathrm{C} \pm \mathrm{SD}\right)$ at Toolik Field Station during the study period

samples were taken during periods I, II, and IV as defined in Fig. 2. Water was taken as grab samples from approximately the middle of the stream channel using a 1-L polycarbonate bottle attached to a pole. Since the stream is small and well mixed, we relied on one sample to represent the entire stream at each sampling time. Stream water was collected in polycarbonate bottles and transported on ice to Toolik Field Station for processing. All samples were filtered through precombusted GF/F filters $(\sim 0.7 \mu \mathrm{m}$ pore size) using a peristaltic pump. Subsamples for ammonium $\left(\mathrm{NH}_{4}{ }^{+}\right), \mathrm{NO}_{3}{ }^{-}$, total dissolved nitrogen (TDN), soluble reactive phosphorus (SRP) and silicate analyses were collected in HDPE bottles and frozen immediately. Samples for DOC analysis were collected in polycarbonate bottles and also frozen immediately.

Dissolved $\mathrm{NH}_{4}{ }^{+}$and SRP were determined at Toolik Field Station using the orthophthaldialdehyde and phosphomolybdate methods, respectively (Holmes et al. 1999; Strickland and Parsons 1972). Nitrate, silicate, and total dissolved nitrogen (TDN) were measured at the Woods Hole Research Center using a Lachat QuikChem 8000 flow injection analyzer using standard colorimetric methods (Strickland and Parsons 1972). DOC was analyzed with a Shimadzu Vcsh TOC analyzer at the Marine Biological Laboratory. DON concentrations were calculated as $[\mathrm{TDN}]-\left[\mathrm{NO}_{3}{ }^{-}\right]-\left[\mathrm{NH}_{4}{ }^{+}\right]$.

In order to model total fluxes of constituents, we used a version of the "worked record" approach (Cohn 1995; Coats et al. 2002) to predict stream constituent concentrations during periods without nutrient measurements. We plotted the continuous record of stream discharge (at 15 min intervals) and interpolated concentrations between measurements 
using a linear relationship of concentration versus discharge with two to four concentration measurements bracketing the discharge record in question. The worked record method is likely most accurate during periods where samples were taken over a range of discharge values within a short time period, such as the spring melt and late summer storm in the upper Kuparuk in 2006. In the mid-summer, concentration measurements were more sporadic, so the exact response of constituents to changing discharge is harder to estimate. Although the upper Kuparuk River was gauged in 2006 until early September (with actual stream flow likely extending into October), our last sample was taken in late July. Our flux modeling, therefore, only extends until the end of July.

For calculation of relationships between constituent concentration and stream discharge, statistical significance of regression relationships was determined using tables of significance of $r$ (Zar 1999). We used the analysis of covariance (ANCOVA) test to measure differences in regressions between study years. Significance was defined as $p<0.05$.

\section{Results}

Water discharge in the upper Kuparuk River during the study period is shown in Fig. 2a. For comparison, discharge in the Kuparuk River at the mouth is shown as well. At the Kuparuk mouth, the highest discharge event was during the spring snowmelt, corresponding with air temperatures rising above freezing (Fig. 2c), whereas in the headwaters the highest discharge was recorded later in the summer during a prolonged rainstorm (Fig. 2b). It should be noted that the very high latitude and relatively small size of the Kuparuk River means that it is completely frozen for a large part of the year, with no discharge (even under ice) during about November through late May or early June. The discharge record for the upper Kuparuk is from May 16 through September 1, 2006; however, the current study focuses on the sampling period from May 15 through July 26 (Fig. 2b). The first sample was taken on May 15 before measurable discharge was recorded. We divided the hydrograph for this period into four sections for more detailed analysis (Fig. 2b). Time period I (5/15/06-5/24/06) captures the initial snowmelt pulse. Time period II (5/25/06-6/ $5 / 06$ ) captures a second snowmelt pulse. Time period
III (6/6/06-7/18/06) captures several intermediate sized rain events during the middle of the study period. Time period IV (7/19/06-7/26/06) captures the largest rain event of the summer. For the entire study period (5/15 through $7 / 26)$, the river discharge was $0.017 \mathrm{~km}^{3}$. Of this, $12.4 \%$ occurred during period I, $12.7 \%$ during period II, $56.7 \%$ during period C, and $18.2 \%$ during period IV.

Concentrations of inorganic nutrients $\mathrm{NO}_{3}{ }^{-}$, $\mathrm{NH}_{4}{ }^{+}, \mathrm{SRP}$, and silicate) and DOC and DON throughout the study period are shown in Fig. 3. The earliest points for each constituent were collected shortly after water began to flow in the river channel. These samples had higher concentrations of $\mathrm{NO}_{3}{ }^{-}$ $(6.7 \mu \mathrm{M}), \mathrm{NH}_{4}{ }^{+}(0.54 \mu \mathrm{M})$, and $\mathrm{SRP}(0.27 \mu \mathrm{M})$ than at any other time during the year, but dropped quickly as discharge increased to an initial peak due to snowmelt runoff. In contrast, DOC and DON concentrations reach their annual maximum $(1316 \mu \mathrm{M}$ and $41.5 \mu \mathrm{M}$, respectively) with the initial peak in snowmelt runoff. Throughout the study period, there was a negative relationship of constituent concentration with time for SRP, DOC, DON $(p<0.0001)$ and $\mathrm{NH}_{4}{ }^{+}(p=0.003)$. Silicate concentrations increased over time $(p<0.0001)$. There was no statistically significant relationship of $\mathrm{NO}_{3}{ }^{-}$concentration with time (average concentration $=1.6 \mu \mathrm{mol} 1^{-1}$ ). In all cases, temporal trends were complicated by linkages between concentrations and discharge across a highly variable hydrograph. The most abundant form of dissolved $\mathrm{N}$ in the stream was DON, which was about $90 \%$ of TDN on average. Overall, the organic fraction of the dissolved $\mathrm{N}$ pool was highest in the beginning of the study and decreased throughout the summer.

While the data in Fig. 3 show broad patterns of change over the study period, comparisons among individual events during the spring and summer demonstrate how discharge-constituent relationships change with time. We specifically focus on the initial snowmelt peak, a second snowmelt peak directly following the first, and a large rainfall event in late July (Periods I, II, and IV in Fig. 2). Relationships between dissolved constituents and discharge for these three events are shown in Fig. 4, and the associated regression statistics are provided in Table 1. Data coverage during period III (Fig. 2) was not sufficient to isolate individual events.

For all of the dissolved inorganic constituents (Fig. 4), concentrations were negatively correlated 
Fig. 3 Dissolved constituent concentrations throughout the study period in the upper Kuparuk River. Also shown in each panel is stream discharge at $15-\mathrm{min}$ intervals in the upper Kuparuk
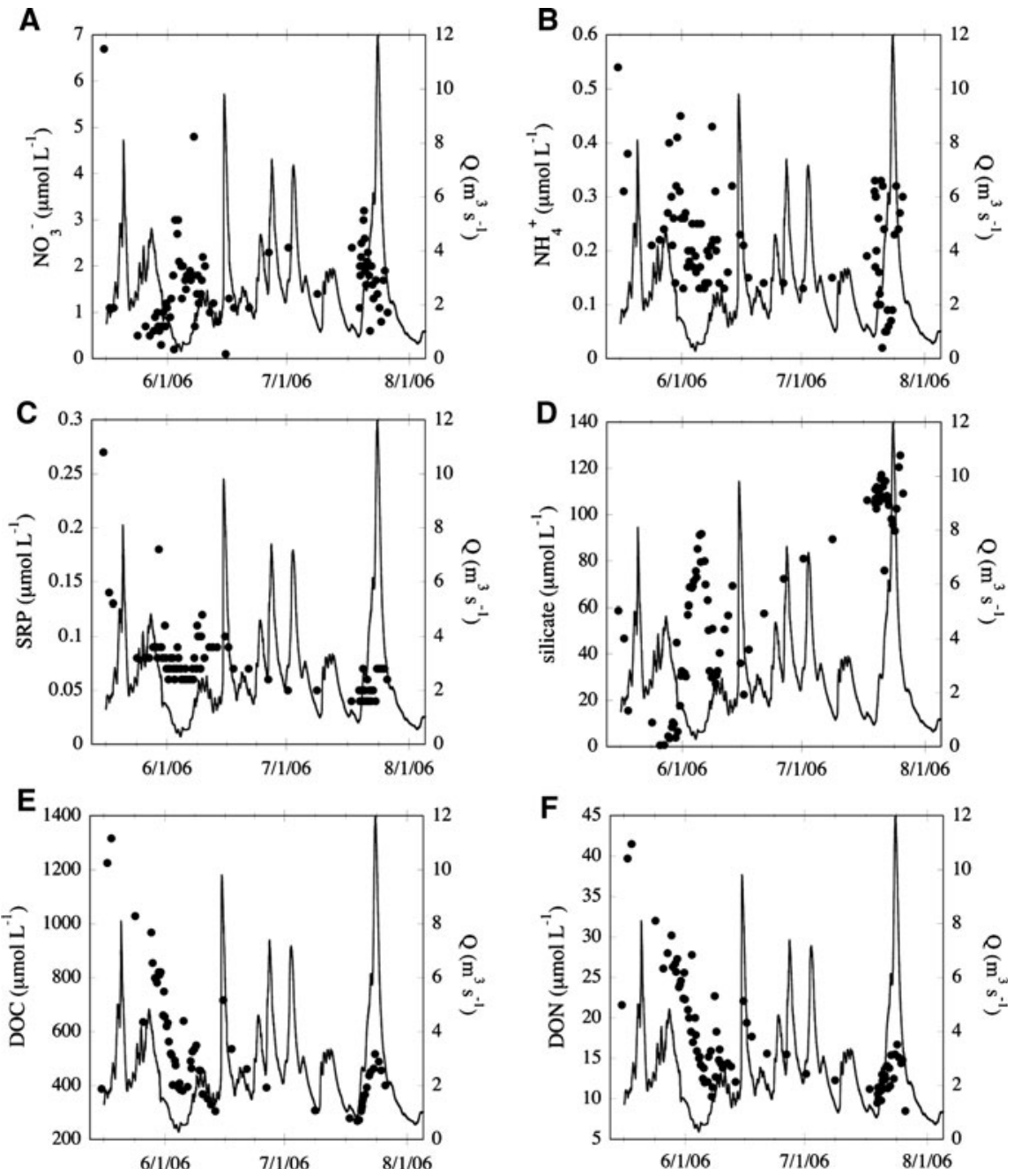

with discharge in the first time period. Statistical uncertainty with respect to individual constituents is relatively high (i.e., $p>0.05$ for $\mathrm{NH}_{4}{ }^{+}$and silicate) during this time period because of limited data coverage, but the consistency in response among inorganic constituents suggests that the patterns are robust (Table 1). Correlations between concentration and discharge remained negative for $\mathrm{NO}_{3}{ }^{-}$and silicate during subsequent events, whereas the correlations are less consistent across events for SRP and $\mathrm{NH}_{4}{ }^{+}$. It is noteworthy, however, that in all cases the slopes of the regression relationships decreased later in the summer (Table 1). Comparing relationships of each constituent with flow over time shows that $\mathrm{NO}_{3}{ }^{-}$ and silicate concentrations at any given discharge (discharge-specific concentrations) increase as the season progresses (Fig. 4a and d) whereas dischargespecific SRP concentrations decrease (Fig. 4b).

In contrast with the dissolved inorganic constituents, concentrations of DOC and DON were positively correlated with discharge in the initial time period (Fig. 4e and f). Slopes relating dissolved OM concentration and discharge decreased over the summer, but discharge continued to explain a large proportion of the variability in dissolved OM concentrations (Table 1). As observed for SRP, discharge-specific concentrations of dissolved $\mathrm{OM}$ decreased as the summer progressed (Fig. $4 \mathrm{e}$ and f).

We also graphed the relationships shown in Fig. 4 according to the method of Evans and Davies (1998) in order to determine if concentrations at a given discharge differed on the rising and falling limbs of 
Fig. 4 Relationship between dissolved constituent concentrations and discharge $(\mathrm{Q})$ for time periods I, II, and IV as defined in Fig. 2. Note that for nitrate, data are presented versus $\log \mathrm{Q}$
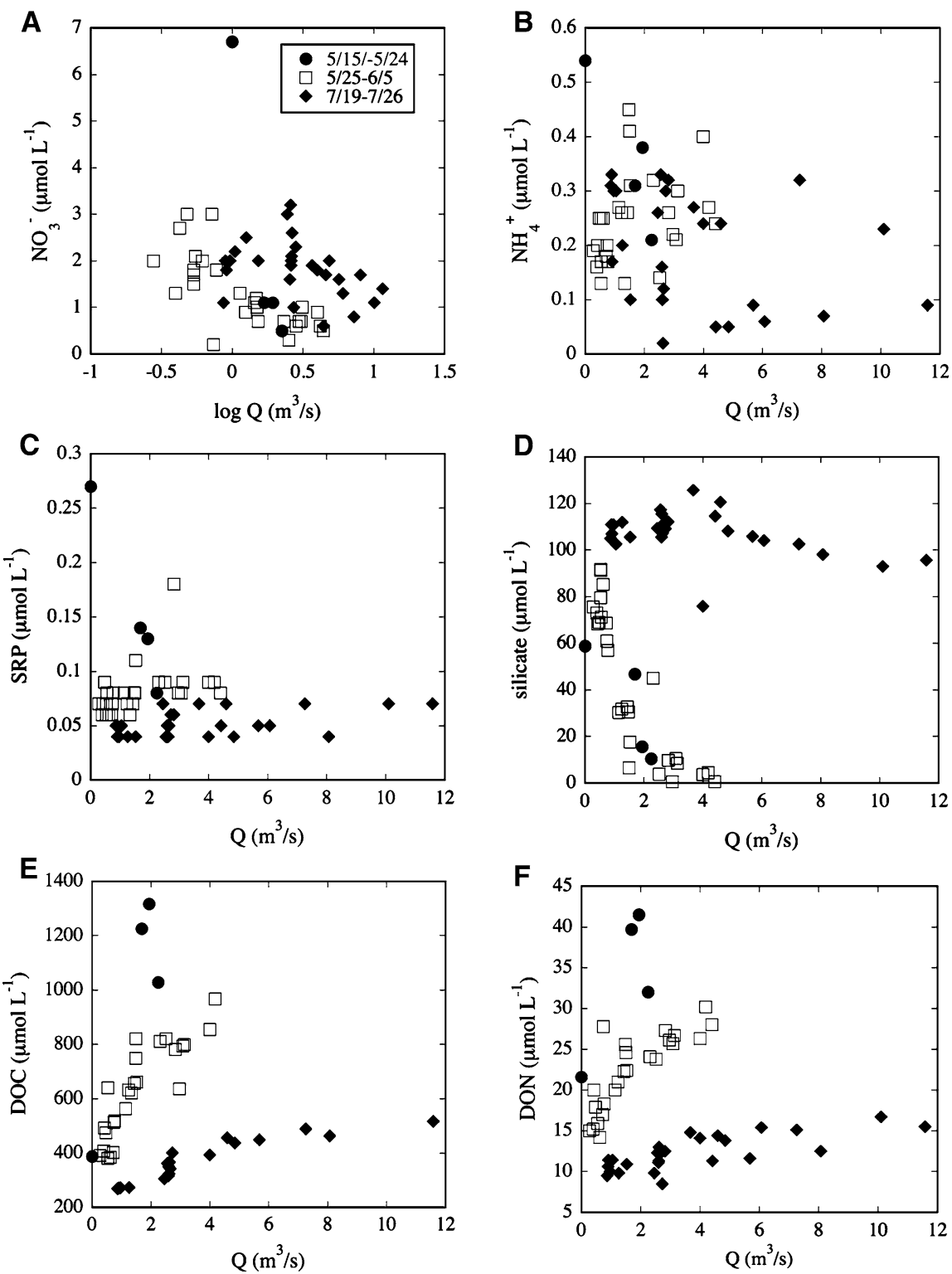

the hydrograph during the snowmelt (Periods I and II, Fig. 2b) and during the summer storm (Period IV). Aside from the very high concentrations of $\mathrm{NO}_{3}{ }^{-}$and $\mathrm{NH}_{4}{ }^{+}$at the onset of flow in the spring, there are no clear differences in discharge-concentration relationships between the rising and falling limbs of the hydrographs during the snowmelt period (Fig. 5a, c). In contrast, $\mathrm{NO}_{3}{ }^{-}$and $\mathrm{NH}_{4}{ }^{+}$concentrations did show some notable differences between the rising and falling limbs of the hydrograph during the midsummer storm (Fig. 5b, c). Concentrations of $\mathrm{NO}_{3}{ }^{-}$ were generally lower on the falling limb as compared to the rising limb, while concentrations of $\mathrm{NH}_{4}{ }^{+}$ showed the opposite pattern. In both cases, differences were most notable toward the higher end of the discharge range. The relationship of DOC with changing stream discharge also differed between the snowmelt period and the mid-summer storm (Fig. 5e and f). During snowmelt, concentrations were higher on the rising limb of the hydrograph, but during the mid-summer storm, concentrations were higher during the falling hydrograph. A similar pattern was shown for DON concentrations during the spring snowmelt, but there was no clear hysteresis during the 
Table 1 Regression statistics for the relationship of various constituents (in $\mu \mathrm{mol}^{-1}$ ) with river discharge (Q; $\mathrm{m}^{3} / \mathrm{s}$ ) in the upper Kuparuk River during time periods I, II, and IV defined in Fig. 2

\begin{tabular}{|c|c|c|c|c|}
\hline Period & Slope & $y$-Intercept & $r^{2}$ & $p$ \\
\hline \multicolumn{5}{|c|}{ I: 5/15-5/24 } \\
\hline $\mathrm{NO}_{3}{ }^{-}$ & -18.4 & 6.33 & 0.935 & 0.0331 \\
\hline $\mathrm{NH}_{4}^{+}$ & -0.13 & 0.55 & 0.836 & 0.0857 \\
\hline SRP & -0.08 & 0.27 & 0.983 & 0.0085 \\
\hline Silicate & -20.0 & 62.3 & 0.726 & 0.1479 \\
\hline DOC & 369 & 447 & 0.786 & 0.1134 \\
\hline DON & 7.08 & 23.3 & 0.615 & 0.2158 \\
\hline \multicolumn{5}{|c|}{ II: $5 / 25-6 / 5$} \\
\hline $\mathrm{NO}_{3}^{-}$ & -1.57 & 1.43 & 0.531 & $<0.0001$ \\
\hline $\mathrm{NH}_{4}^{+}$ & 0.02 & 0.20 & 0.130 & 0.0599 \\
\hline SRP & 0.01 & 0.07 & 0.193 & 0.0191 \\
\hline Silicate & -21.4 & 76.9 & 0.732 & $<0.0001$ \\
\hline DOC & 126 & 429 & 0.739 & $<0.0001$ \\
\hline DON & 2.96 & 17.0 & 0.665 & $<0.0001$ \\
\hline \multicolumn{5}{|c|}{ IV: 7/19-7/26 } \\
\hline $\mathrm{NO}_{3}^{-}$ & -0.70 & 2.15 & 0.142 & 0.0531 \\
\hline $\mathrm{NH}_{4}^{+}$ & -0.01 & 0.23 & 0.095 & 0.1181 \\
\hline $\mathrm{SRP}^{-}$ & 0.00 & 0.04 & 0.224 & 0.0127 \\
\hline Silicate & -1.37 & 112 & 0.168 & 0.0337 \\
\hline DOC & 25.9 & 275 & 0.821 & $<0.0001$ \\
\hline DON & 0.55 & 10.2 & 0.553 & $<0.0001$ \\
\hline
\end{tabular}

The nitrate statistics are for concentration versus $\log \mathrm{Q}$; all other statistics are for simple linear regressions

mid-summer storm. For SRP, the initial sample taken before the spring flow began was higher than all other samples taken during that period, but otherwise there was no pattern of hysteresis detectable in these data for either period. There was also no pattern of hysteresis evident in silicate concentrations.

Fluxes of DOC, DON, and nutrients are presented in Table 2. Our data show that the spring snowmelt period is an important time for organic matter and nutrient export in Arctic rivers. Over 30\% of $\mathrm{NH}_{4}{ }^{+}$, SRP, DOC, and DON export between mid May and the end of July occurred between May 15 and June 5 . Furthermore, the percentages of $\mathrm{NH}_{4}^{+}$, SRP, DOC, and DON export were greater than the percentage of water export during that period. The large storm in late July also contributed significantly to total $\mathrm{NH}_{4}{ }^{+}$, SRP, DOC, and DON export, but in this case their percentages were lower than the percentage of water export. Nitrate and silicate differed strongly from the other constituents, showing much larger percentages of export during the mid-summer storm than the spring snowmelt period. As noted above, our flux calculations were not extended beyond the sampling period (mid-May-July), although our study period likely captured the bulk of stream discharge for the year.

\section{Discussion}

Our results show distinct temporal shifts in patterns of nutrient and OM export in the upper Kuparuk River over the spring and summer, indicating a high degree of sensitivity to changes in river discharge and seasonal changes such as temperature, depth of thaw, soil moisture, and precipitation phase. Although the upper Kuparuk River has been sampled for water chemistry as a component of the Arctic LTER project for more than 25 years, the spring snowmelt period has only rarely been sampled. Furthermore, sampling frequency has not generally been sufficient to resolve individual events (with the exception of McNamara et al. 2008). Thus, the data presented here significantly advance our understanding of nutrient and organic matter export dynamics in the upper Kuparuk River and provide an improved basis for analysis of future changes within the Arctic LTER domain. This work also highlights the importance of the spring snowmelt period with respect to estimation of Arctic river export more generally, as this period has been under-sampled throughout much of the pan-Arctic watershed (e.g., Lara et al. 1998).

\section{Seasonal variations in constituent export}

Major export of DOC during the spring snowmelt period has been documented in other studies. For example, (Finlay et al. 2006) estimated that about $55 \%$ of the total DOC flux from the Kolyma River in Siberia occurs during the spring snowmelt. Similarly, studies of the Yenisey, Ob', Mackenzie, and Yukon Rivers showed that about $60 \%$ of annual DOC export occurred during the 2 months following snowmelt (Raymond et al. 2007). Another recent study estimated that, at the lower Kuparuk River (which, although much larger than the upper Kuparuk, is still frozen most of the year), more than one-third of the 
Fig. 5 Concentrationdischarge plots for $\mathrm{NO}_{3}{ }^{-}$ $(\mathrm{A}+\mathrm{B}), \mathrm{NH}_{4}^{+}(\mathrm{C}+\mathrm{D})$, and DOC $(\mathrm{E}+\mathrm{F})$ during snowmelt and during the midsummer storm (periods I and II, and period IV from Fig. 2b, respectively). The solid lines and symbols represent samples taken during the rising hydrograph, and the open symbols and dashed lines represent samples taken during the falling hydrograph
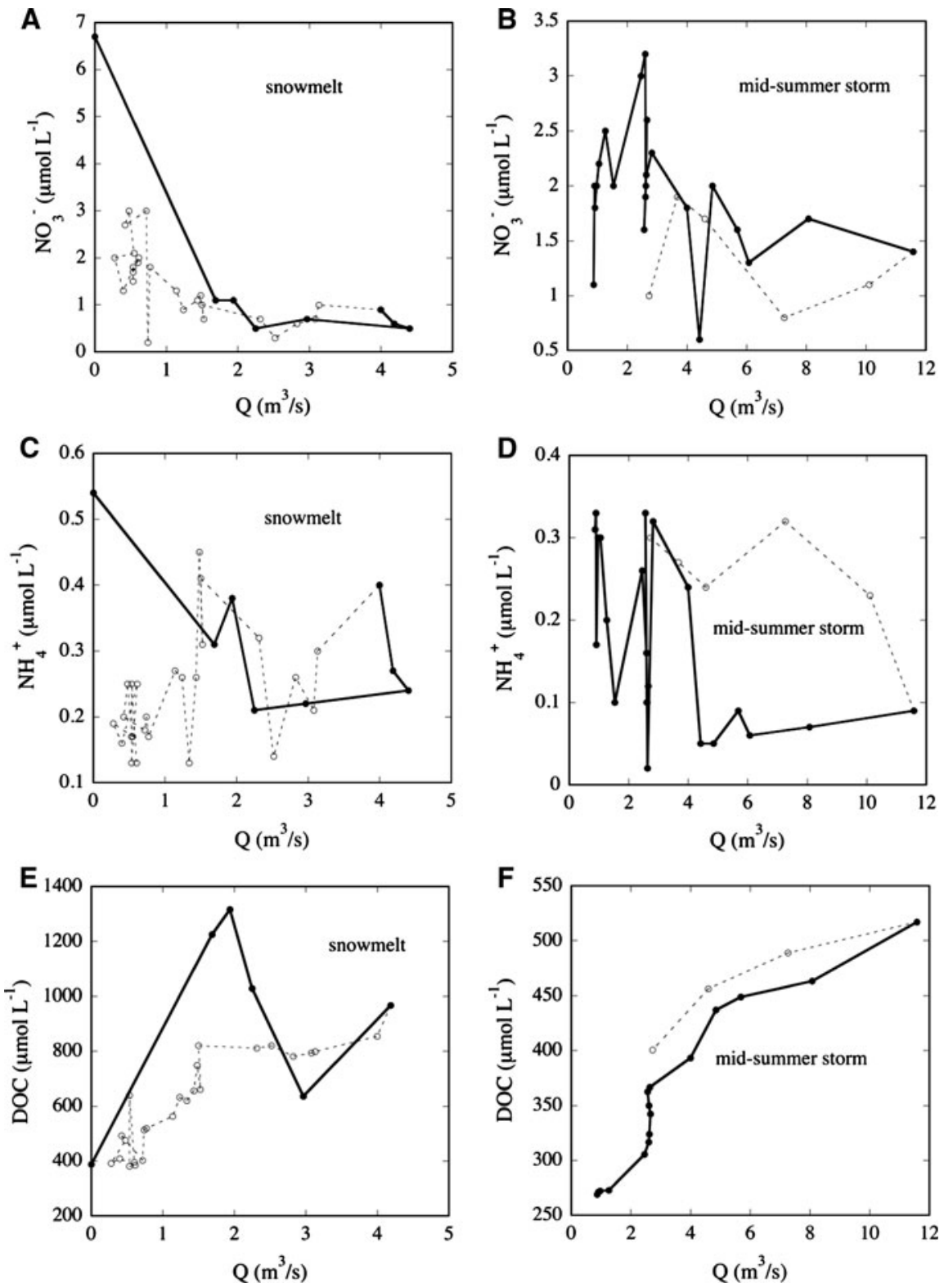

annual DOC flux to the coastal ocean occurred during just 3 days of spring snowmelt (Rember and Trefry 2004). Our results for DOC are consistent with the previous work on DOC export around the pan-Arctic domain. These findings have important implications for understanding future changes in carbon export in the Arctic, especially as climate warming contributes to a shift in the relative amounts of snowmelt versus rainfall. Far less work has focused on export of DON, however the similar patterns that we have shown for DON and DOC in the upper Kuparuk River suggest that there will be concomitant changes in DON export.

The relationships we have shown for constituent concentration versus discharge over the spring/summer (Fig. 4) are indicative of a shift in biogeochemical processes and hydrologic flowpaths over time. For example, it is likely that increased microbial decomposition or photodegradation during the summer months contributes to lower DOC concentrations per unit of discharge as the summer progresses. A recent study of bioavailability of DOC in the upper 
Table 2 Fluxes of water and stream constituents (in kg/interval or tons/interval), calculated using the "worked record" method, during the time periods defined in Fig. 2

\begin{tabular}{|c|c|c|c|c|c|c|c|}
\hline Period & $\begin{array}{l}\mathrm{Q} \\
\left(\mathrm{m}^{3} / \mathrm{int}\right)\end{array}$ & $\begin{array}{l}\mathrm{NO}_{3}{ }^{-} \\
\text {(kg/int) }\end{array}$ & $\begin{array}{l}\mathrm{NH}_{4}^{+} \\
(\mathrm{kg} / \mathrm{int})\end{array}$ & $\begin{array}{l}\text { SRP } \\
\text { (kg/int) }\end{array}$ & $\begin{array}{l}\text { Silicate } \\
\text { (tons/int) }\end{array}$ & $\begin{array}{l}\text { DOC } \\
\text { (tons/int) }\end{array}$ & $\begin{array}{l}\text { DON } \\
\text { (tons/int) }\end{array}$ \\
\hline I: $5 / 15-5 / 24$ & $2.1 \times 10^{6}$ & 17.8 & 7.6 & 5.7 & 0.6 & 24.2 & 0.9 \\
\hline II: $5 / 25-6 / 5$ & $2.2 \times 10^{6}$ & 24.2 & 8.0 & 5.9 & 0.8 & 17.9 & 0.8 \\
\hline III: $6 / 6-7 / 18$ & $9.8 \times 10^{6}$ & 353.0 & 23.9 & 20.9 & 16.4 & 54.2 & 2.2 \\
\hline IV: 7/19-7/26 & $3.2 \times 10^{6}$ & 69.6 & 7.8 & 5.8 & 9.3 & 17.7 & 0.6 \\
\hline TOTAL (5/15-7/26) & $\begin{array}{c}1.7 \times 10^{7} \\
\% \text { of total }\end{array}$ & 464.6 & 47.4 & 38.3 & 27.1 & 114.0 & 4.5 \\
\hline Snowmelt (I + II) & 25.1 & 9.0 & 33.0 & 30.3 & 5.1 & 36.9 & 37.2 \\
\hline Storm (IV) & 18.2 & 15.0 & 16.5 & 15.1 & 34.2 & 15.6 & 13.7 \\
\hline
\end{tabular}

Kuparuk River showed that $20-40 \%$ of the DOC transported by rivers in the early spring is microbially available, while late-summer DOC is much less labile (Holmes et al. 2008). Seasonally varying UV photolysis (Wetzel et al. 1995) may also contribute to changes in discharge-specific DOC concentrations as the summer progresses. At the same time, water movement along deeper flow paths as the soil active layer extends over the summer may reduce DOC concentrations as a consequence of adsorption in mineral soils. Earlier work in the upper Kuparuk River showed that stream water in the initial snowmelt period is nearly all "new" water (i.e., freshly melted ice or snow), whereas during mid-summer storms, increases in stream discharge are from soil waters flushed into streams by precipitation (or "old" water) (McNamara et al. 1997).

Different patterns of hysteresis for $\mathrm{NO}_{3}{ }^{-}, \mathrm{NH}_{4}{ }^{+}$, and DOC (Fig. 5) provide further details with respect to nutrient and organic matter mobilization. Major increases in DOC concentrations after the onset of river flow in the spring are consistent with flushing of melt water that has leached DOC from saturated vegetation and organic rich surface soils before significant runoff begins. DOC concentrations are diluted on the descending limb of the hydrograph, similar to behavior shown during flushing in other streams (Hood et al. 2006). High DOC concentrations during the initiation of this event are likely moderated by biological or physical degradation as the event continues. In contrast, rapid decreases in $\mathrm{NO}_{3}{ }^{-}$and $\mathrm{NH}_{4}{ }^{+}$concentrations after the onset of river flow in spring suggest that inorganic $\mathrm{N}$ concentrations in water from snowmelt are minimal. During the mid summer storm, concentrations of DOC may be lower on the ascending limb of the hydrograph (Fig. 5f) due to increased drainage between runoff events. In this case, greater saturation of surface layers as the storm progresses promotes greater leaching of DOC. At the same time, higher $\mathrm{NH}_{4}{ }^{+}$and lower $\mathrm{NO}_{3}{ }^{-}$on the falling limb of the hydrograph during the mid summer storm may be linked to changes in soil oxidation state as surface layers become increasingly saturated with water.

In contrast to our findings, McNamara et al. (2008) showed essentially no hysteresis of $\mathrm{NH}_{4}{ }^{+}$and $\mathrm{NO}_{3}{ }^{-}$ in the upper Kuparuk River during extended wet conditions during the mid-1990s. However, similar to the results of the present study, hysteresis in concentration-discharge relationships for $\mathrm{NO}_{3}{ }^{-}$and $\mathrm{NH}_{4}{ }^{+}$ were also demonstrated over a large summer storm event in a nearby stream in the Toolik Lake watershed (MacIntyre et al. 2006). In this case, $\mathrm{NO}_{3}{ }^{-}$concentrations were high during the rising limb of the hydrograph, but also increased as discharge dropped following the storm (MacIntyre et al. 2006). That same study showed that $\mathrm{NH}_{4}{ }^{+}$concentrations during the storm remained elevated over the course of the storm, even several days after discharge returned to baseflow (MacIntyre et al. 2006). This and the current study demonstrates that nutrients are present in very large quantities in Arctic soils, indicating that greater summer precipitation may increase the proportion of soil $\mathrm{N}$ that is exported from the watershed.

In the Arctic, significant $\mathrm{N}$ mineralization in soils happens during the winter, under the snowpack (Hobbie and Chapin 1996; Schimel et al. 2004), leading to high levels of $\mathrm{NH}_{4}{ }^{+}$when snow initially 
melts. High in-stream demand for $\mathrm{NH}_{4}{ }^{+}$by nitrifying microbes has been shown in the Kuparuk River (Wollheim et al. 2001). Nitrification rates have not been measured in soils at the Arctic LTER, but nitrification has been hypothesized as a strong control on total dissolved $\mathrm{N}$ export in the Kuparuk (McNamara et al. 2008). Our data show a strong correlation of $\mathrm{NH}_{4}{ }^{+}$concentration with stream discharge in the initial study period (Fig. 4), but no relationship in later periods indicating that, besides stream flow, there is a more important process influencing $\mathrm{NH}_{4}{ }^{+}$ export, such as nitrification or microbial or plant uptake. The idea that nitrification increases throughout the summer is supported by greater export of $\mathrm{NO}_{3}{ }^{-}$(Table 2) and a stronger correlation of $\mathrm{NO}_{3}{ }^{-}$ concentration with river discharge as the summer progresses (Fig. 4, Table 1). The relationship of $\mathrm{NO}_{3}{ }^{-}$with discharge is also much different than that of other constituents, as the correlation improves with $\log$ transformation of the discharge data. A linear relationship of concentration with discharge indicates a two-source mixing model for nutrient sources: in other words, dilution of stream water with a low concentration source such as rainwater. A logarithmic relationship of concentration to discharge indicates that an additional biological or chemical transformation (such as the addition of $\mathrm{NO}_{3}{ }^{-}$via nitrification) is affecting concentration patterns. Future studies are needed to determine whether nitrification rates in soils increase as soils warm and flowpaths change.

Like $\mathrm{NH}_{4}{ }^{+}$, decreases in SRP concentration over the spring/summer period are consistent with increasing biogeochemical activity. SRP is the limiting nutrient for primary producers within the stream (Peterson et al. 1992), and rapid uptake rates largely decouple SRP concentrations from variations in river discharge after the initial snowmelt period. While there is a positive correlation between SRP and discharge during mid-summer (this study; McNamara et al. 2008), the change in SRP concentration with increasing discharge is very small. The spike in SRP concentration in the initial snowmelt period is similar to that shown in McNamara et al. (2008) and may represent $\mathrm{P}$ mobilized during microbial mineralization of biomass during the winter.

In contrast to $\mathrm{NH}_{4}^{+}$and SRP, increasing silicate concentrations over the spring/summer period are likely due to changes in geochemistry rather than biogeochemistry. This pattern has been demonstrated in other Arctic streams in Siberia and Alaska (MacLean et al. 1999; Frey et al. 2007b; Frey and McClelland 2009). The observed pattern may be due to increased inputs of silicate rich groundwater in late summer, perhaps due to enhanced mineral leaching along longer flow paths through deeper soils as temperatures rise and thaw depths increase.

\section{Changes in $\mathrm{C}$ and $\mathrm{N}$ flux in the Kuparuk River}

The upper Kuparuk River has been sampled for dissolved nutrient and organic C concentrations several times a year since 1978, but in 1980 and the mid-1990s, the stream was sampled more frequently in studies similar in design to the one presented here (Peterson et al. 1986, 1992; McNamara et al. 2008). The current study offers a unique opportunity to compare datasets and consider potential changes in stream chemistry that may have occurred over the past 26 years.

The relationship between DOC concentration and river discharge remained relatively constant over the period of 1980-2006. The slope and $y$-intercept values for DOC versus discharge during periods II, III and IV combined in 2006 (the previous study did not include data from the initial snowmelt, so these data from 2006 have been removed for the purposes of comparison) were +16.3 and +457 , respectively $(p<0.0001)$. These are not significantly different $(p=5.01$; ANCOVA) from slope and y-intercept values of +14.1 and +458 in $1980(p<0.0001$; Peterson et al. 1986). These findings are consistent with the analysis of McClelland et al. (2007), who showed that, although DOC export from the Kuparuk watershed decreased in the 1990s, this was largely attributable to lower spring discharge rather than a change in discharge-specific concentrations.

Comparison with earlier studies does indicate a change in $\mathrm{N}$ cycling and export in the upper Kuparuk watershed. Peterson et al. (1992) report slope and $y$-intercept values of -1.56 and +2.25 , respectively, for $\mathrm{NO}_{3}{ }^{-}$concentration versus $\log _{10}$ discharge in the upper Kuparuk River in 1980 ( $p<0.05)$. In contrast, $\mathrm{NO}_{3}{ }^{-}$concentration versus $\log _{10}$ discharge for periods II, III, and IV combined during 2006 resulted in a slope of -0.65 and $y$-intercept of $+1.76(p<0.001)$. The difference in slopes between 1980 and 2006 is statistically significant at $p=0.003$ (ANCOVA). 
The 2.4 fold difference in slope values between 1980 and 2006 is indicative of higher $\mathrm{NO}_{3}{ }^{-}$concentrations at high flow during recent years. Nitrate concentrations remain negatively correlated with discharge (also reported for the 1990s in McNamara et al. (2008)), but, in recent years, concentrations are not as strongly diluted during high flow.

This is demonstrated in our results showing greater nitrate export in the mid-summer storm than in the spring snowmelt period (Table 2), which are in contrast with results from the 1990s, when the spring snowmelt accounted for a greater proportion of the annual export (McNamara et al. 2008). Furthermore, $\mathrm{NO}_{3}{ }^{-}$export during our study (5/15/06-7/26/06) was $\sim 10 \%$ higher than the estimate of average annual $\mathrm{NO}_{3}{ }^{-}$export during 1994-1996 calculated by McNamara et al. (2008). Of course, individual years may have vastly different hydrographs, affecting these patterns of proportional nutrient export, and $\mathrm{McNa}-$ mara et al. (2008) did not report water flux for the upper Kuparuk. However, a recent analysis of historical data in the upper Kuparuk watershed has shown that total annual $\mathrm{NO}_{3}{ }^{-}$export has increased between the early 1970s and the 2000s, with a particularly marked increase in $\mathrm{NO}_{3}{ }^{-}$export per unit stream discharge after 2001 (McClelland et al. 2007). Our results, in combination with those of earlier studies (Peterson et al. 1986, 1992; McNamara et al. 2008) support this finding and indicate that an increase in total $\mathrm{NO}_{3}{ }^{-}$export from the watershed may be due to an increase in $\mathrm{NO}_{3}{ }^{-}$export during summer storms.

The increase in $\mathrm{NO}_{3}{ }^{-}$export per unit stream discharge may be due to an increase in $\mathrm{N}$ mineralization or nitrification rates in soils. Experiments in the Kuparuk region have shown that warming can result in large increases in net $\mathrm{N}$ mineralization in soils (Shaver et al. 1992, 1998), without a concurrent increase in productivity (Johnson et al. 2000). Nitrification rates in the upper Kuparuk River are rapid (Wollheim et al. 2001), but the effects of temperature on in-stream nitrification rates have not been tested directly. It has been suggested that warming will increase mobilization of soil DOC and DON due to exposure of previously frozen organic material (Frey et al. 2007a; Frey and McClelland 2009). This change might not be reflected in DOC and DON concentrations, since this material is rapidly consumed in the stream, especially during spring snowmelt (Holmes et al. 2008). In other words, an increase in export of terrestrial organic matter combined with rapid in-stream transformations of DOC and DON might be responsible for the observed increase in $\mathrm{NO}_{3}{ }^{-}$concentrations.

Because we have shown that the relationship between stream discharge and $\mathrm{NO}_{3}{ }^{-}$concentration is sensitive to seasonal changes such as temperature and precipitation, a change in timing and magnitude of streamflow in the upper Kuparuk River may also explain the observed changes in $\mathrm{NO}_{3}{ }^{-}$export. Total freshwater discharge to the Arctic Ocean has increased over the past $\sim 50$ years (Peterson et al. 2002), and one study has shown that, in Alaska, at least, this may be due to increased river discharge during low-flow periods (Lammers et al. 2001). Discharge measurements in the upper Kuparuk generally end in the middle of summer, including in the year of our study, so we lack good information about potential changes in the total distribution of streamflow over the whole hydrograph. In addition, although we made a concerted effort in the current study to capture nutrient and organic matter export during the understudied spring snowmelt period, to our knowledge, no studies have sampled the tail end of the hydrograph in this (or any other) Arctic watershed. Given that summer storms can exert large controls over total annual nutrient and organic matter export (this study; MacIntyre et al. 2006; McNamara et al. 2008), perhaps future studies would benefit from combining constituent and discharge measurements during "freeze-up". An increase in summer and fall stream discharge in Arctic watersheds combined with greater discharge-specific concentrations of $\mathrm{NO}_{3}{ }^{-}$in these periods may lead to increasing export of $\mathrm{NO}_{3}{ }^{-}$from Arctic watersheds in the future, with implications for coastal and terrestrial $\mathrm{N}$ budgets and productivity.

Previous studies have suggested that Arctic streams export a greater proportion of primary productivity as compared to temperate and tropical watersheds (Peterson et al. 1986; Harvey et al. 1997; Waddington and Roulet 1997; McGuire et al. 2009). As temperatures warm in the Arctic and soils thaw, the balance of $\mathrm{C}$ fixed by plants and released, either to the atmosphere as $\mathrm{CO}_{2}$ or $\mathrm{CH}_{4}$ or in streams as DOC or dissolved inorganic $\mathrm{C}$, is expected to change (McGuire et al. 2002, 2009), but the magnitude and direction of this change is unknown. Peterson et al. 
(1986) estimated C stocks in the Kuparuk watershed to compare to hydrologic export, but since then no systematic study of the $\mathrm{C}$ budget of the watershed has been conducted. Even less is known about the proportion of terrestrial $\mathrm{N}$ and $\mathrm{P}$ exported by Arctic streams. Mineralization of soil organic matter will likely increase with higher temperatures (Nadelhoffer et al. 1991; Hobbie 1996; Mack et al. 2004), which would likely increase the proportion of mineralized $\mathrm{N}$ and $\mathrm{P}$ exported as $\mathrm{NO}_{3}{ }^{-}$and $\mathrm{SRP}$, respectively. However, previous studies (including the current study) have not combined measurements of soil $\mathrm{N}$ stocks and cycling rates with stream constituent measurements. Future studies would benefit from combining measurements of $\mathrm{C}$ and nutrient cycling in the stream with measurements in riparian soils in order to elucidate how these reservoirs respond to changes in temperature and hydrology.

\section{Conclusions}

While the exact response of stream discharge in the Arctic to climate change is still under investigation, characterization of discharge-constituent relationships will help determine the biogeochemical consequences of changing Arctic hydrology. The results of this study highlight seasonal changes in dischargeconstituent relationships and, in particular, disproportionate fluxes of organic matter and some nutrients that occur during the snowmelt period. Robust estimates of annual export from Arctic rivers require a better understanding of the initiation of stream flow: an important yet understudied component of the hydrograph. Our study also provides evidence for a building awareness of increased $\mathrm{NO}_{3}{ }^{-}$export from the upper Kuparuk watershed over the past $\sim 30$ years, perhaps due in part to changing hydrology. Clearly, hydrology and biogeochemistry are linked in small Arctic watersheds, and changes in river discharge will have implications for soil $\mathrm{C}$ and nutrient budgets, stream productivity, and timing and magnitude of export of bioreactive elements to coastal ecosystems.

Acknowledgements Toolik Field Station and the Institute for Arctic Biology at the University of Alaska Fairbanks provided valuable field and logistical support. We would like to thank Adrian Green, Christie Haupert, Jorge Noguera, and Breton Frazer for assistance with sample collection and analysis.
Ekaterina Bulygina at the Woods Hole Research Center analyzed total dissolved nitrogen, nitrate, and silica. Funding provided by the National Science Foundation, NSF-OPP0436118.

Open Access This article is distributed under the terms of the Creative Commons Attribution Noncommercial License which permits any noncommercial use, distribution, and reproduction in any medium, provided the original author(s) and source are credited.

\section{References}

Amon RMW, Meon B (2004) The biogeochemistry of dissolved organic matter and nutrients in two large Arctic estuaries and potential implications for our understanding of the Arctic Ocean system. Mar Chem 92:311-330

Anisimov OA, Vaughan DG, Callaghan TV, Furgal C, Marchant H, Prowse TD, Viljhálmsson H, Walsh JE (2007) Polar regions (Arctic and Antarctic). Climate Change 2007: impacts, adaptation, and vulnerability. In: Parry ML, Canziani OF, Palutikof JP, van der Linden PJ, Hanson CE (eds) Contribution of Working Group II to the Fourth Assessment Report of the Intergovernmental Panel on Climate Change. Cambridge University Press, Cambridge, $653-685$

Arctic Climate Impact Assessment (2005) Arctic climate impact assessment. Cambridge University Press, New York $1042 \mathrm{pp}$

Benstead JP, Green AC, Deegan LA, Peterson BJ, Slavik K, Bowden WB, Hershey AE (2007) Recovery of three Arctic stream reaches from experimental nutrient enrichment. Freshwater Biol 52:1077-1089

Burns DA (2005) What do hydrologists mean when they use the term flushing? Hydrol Process 19:1325-1327

Chapin FS III, McGuire AD, Randerson J, Pielke R Sr, Baldocchi D, Hobbie SE, Roulet N, Eugster W, Kasischke E, Rastetter EB, Zimov SA, Running SW (2000) Arctic and boreal ecosystems of western North America as components of the climate system. Global Change Biol 6:211-223

Coats R, Lui F, Goldman CR (2002) A Monte Carlo test of load calculation methods, Lake Tahoe Basin, CaliforniaNevada. J Am Water Res Assoc 38:719-730

Cohn TA (1995) Recent advances in statistical methods for the estimation of sediment and nutrient transport in rivers. Rev Geophys 33(suppl):1-18

Craig PC, McCart PJ (1975) Classification of stream types in Beaufort Sea drainages between Prudhoe Bay, Alaska, and the Mackenzie Delta, N.W.T., Canada. Arctic Alpine Res 7:183-198

Creed IF, Band LE (1998) Export of nitrogen from catchments within a temperate forest: evidence for a unifying mechanism regulated by variable source area dynamics. Water Resour Res 34:3105-3120

Creed IF, Band LE, Foster NW, Morrison IK, Nicolson JA, Semkin RS, Jeffries DS (1996) Regulation of nitrate-N from temperate forests: a test of the $\mathrm{N}$ flushing hypothesis. Water Resour Res 32:3337-3354 
Dittmar T, Kattner G (2003) The biogeochemistry of the river and shelf ecosystem of the Arctic Ocean: a review. Mar Chem 83:103-120

Evans C, Davies TD (1998) Causes of concentration/discharge hysteresis and its potential as a tool for analysis of episode hydrochemistry. Water Resour Res 34:129-137

Finlay J, Neff J, Zimov S, Davydova A, Davydov S (2006) Snowmelt dominance of dissolved organic carbon in highlatitude watersheds: implications for characterization and flux of river DOC. Geophys Res Lett 33:L10401. doi: 10.1029/2006GL025754

Francis JA, White DM, Cassano JJ, Gutowski WJ Jr, Hinzman LD, Holland MM, Steele MA, Vörösmarty CJ (2009) An Arctic hydrologic system in transition: feedbacks and impacts on terrestrial, marine, and human life. J Geophys Res 114:G04019. doi:10:1029/2008JG000902

Frey KE, McClelland JW (2009) Impacts of permafrost degradation on Arctic river biogeochemistry. Hydrol Process 23:169-182

Frey KE, Smith LC (2005) Amplified carbon release from vast West Siberian peatlands by 2100 . Geophys Res Lett 32:L09401. doi:10.1029/2004GL022025

Frey KE, McClelland JW, Holmes RM, Smith LC (2007a) Impacts of climate warming and permafrost thaw on the riverine transport of nitrogen and phosphorus to the Kara Sea. J Geophys Res 112:G04S58. doi:10.1029/2006 JG000369

Frey KE, Siegel DI, Smith LC (2007b) Geochemistry of west Siberian streams and their potential response to permafrost degradation. Water Resour Res 43:W03406. doi: 10.1029/2006WR004902

Giblin AE, Nadelhoffer KJ, Shaver GR, Laundre JA, McKerrow AJ (1991) Biogeochemical diversity along a riverside toposequence in Arctic Alaska. Ecol Monogr 61:415-435

Greenwald MJ, Bowden WB, Gooseff MN, Zarnetske JP, McNamara JP, Bradford JH, Brosten TR (2008) Hyporheic exchange and water chemistry of two Arctic tundra streams of contrasting geomorphology. J Geophys Res 113:G02029. doi:10.1029/2007JG000549

Harvey CJ, Peterson BJ, Bowden WB, Deegan LA, Finlay JC, Hershey AE, Miller MC (1997) Organic matter dynamics in the Kuparuk River, a tundra river in Alaska, USA. J North Am Benth Soc 16:18-23

Hinzman LD, Kane DL, Gieck RE, Everett KR (1991) Hydrologic and thermal properties of the active layer in the Alaskan Arctic. Cold Reg Sci Technol 19:95-110

Hobbie SE (1996) Temperature and plant species control over litter decomposition in Alaskan tundra. Ecol Monogr 66:503-522

Hobbie SE, Chapin FS III (1996) Winter regulation of tundra litter carbon and nitrogen dynamics. Biogeochemistry 35:327-338

Hobbie JE, Peterson BJ, Bettez N, Deegan L, O'Brien WJ, Kling GW, Kipphut GW, Bowden WB, Hershey AE (1999) Impact of global change on the biogeochemistry and ecology of an Arctic freshwater system. Polar Res 18:207-214

Holland MM, Finnis J, Serreze MC (2006) Simulated Arctic Ocean freshwater budgets in the twentieth and twenty-first century. J Clim 19:6221-6242
Holland MM, Finnis J, Barrett AP, Serreze MC (2007) Projected changes in Arctic Ocean freshwater budgets. J Geophys Res 112:G04S55. doi:10.1029/2006JG000354

Holmes RM, Aminot A, Kerouel R, Hooker BA, Peterson BJ (1999) A simple and precise method for measuring ammonium in marine and freshwater ecosystems. Can J Fish Aquat Sci 56:1801-1808

Holmes RM, McClelland JW, Raymond PA, Frazer BB, Peterson BJ, Steiglitz M (2008) Lability of DOC transported by Alaskan rivers to the Arctic Ocean. Geophys Res Lett 35:L03402. doi:10.1029/2007GL032837

Hood E, Gooseff MN, Johnson SL (2006) Changes in the character of stream water dissolved organic carbon during flushing in three small watersheds, Oregon. J Geophys Res 111:G01007. doi:10.1029/2005JG000082

Johnson LC, Shaver GR, Cades DH, Rastetter E, Nadelhoffer K, Giblin A, Laundre J, Stanley A (2000) Plant carbonnutrient interactions control $\mathrm{CO}_{2}$ exchange in Alaskan wet sedge tundra ecosystems. Ecology 81:453-469

Jones JB Jr, Petrone KC, Finlay JC, Hinzman LD, Bolton WR (2005) Nitrogen loss from watersheds of interior Alaska underlain with discontinuous permafrost. Geophys Res Lett 32:L02401. doi:02410.01029/02004GL021734

Kane DL, Hinzman LD (2006) Climate data from the North Slope Hydrology Research project. University of Alaska Fairbanks, Water and Environmental Research Center. URL: http://www.uaf.edu/water/projects/NorthSlope/ Fairbanks, Alaska, variously paged

Kane DL, McNamara JP, Yang D, Olson PQ, Gieck RE (2003) An extreme rainfall event in Arctic Alaska. J Hydromet 4:1220-1228

Lammers RB, Shiklomanov AI, Vörösmarty CJ, Fekete BM, Peterson BJ (2001) Assessment of contemporary Arctic river runoff based on observational discharge records. J Geophys Res 106:3321-3334

Lara RJ, Rachold V, Kattner G, Hubberten HW, Guggenberger G, Skoog A, Thomas DN (1998) Dissolved organic matter and nutrients in the Lena River, Siberian Arctic: characteristics and distribution. Mar Chem 59:301-309

MacIntyre S, Sickman JO, Goldthwait SA, Kling GW (2006) Physical pathways of nutrient supply in a small, oligotrophic Arctic lake during summer stratification. Limnol Oceanogr 51:1107-1124

Mack MC, Schuur EAG, Bret-Harte MS, Shaver GR, Chapin FS III (2004) Ecosystem carbon storage in Arctic tundra reduced by long-term nutrient fertilization. Nature 431:440-443

MacLean R, Oswood MW, Irons JG III, McDowell WH (1999) The effect of permafrost on stream biogeochemistry: a case study of two streams in the Alaskan (U.S.A.) taiga. Biogeochemistry 47:239-267

McClelland JW, Dery SJ, Peterson BJ, Holmes RM, Wood EF (2006) A pan-Arctic evaluation of changes in river discharge during the latter half of the 20th century. Geophys Res Lett 33:L06715. doi:10.1029/2006GL025753

McClelland JW, Steiglitz M, Pan F, Holmes RM, Peterson BJ (2007) Recent changes in nitrate and dissolved organic carbon export from the upper Kuparuk River, North Slope, Alaska. J Geophys Res 112:G04S60. doi:10.1029/ 2006JG000371 
McGuire AD, Wirth C, Apps M, Beringer J, Clein J, Epstein H, Kicklighter DW, Bhatti J, Chapin FS III, de Groot B, Efremov D, Eugster W, Fukuda M, Gower T, Hinzman L, Huntley B, Jia GJ, Kasischke E, Melillo J, Romanovsky V, Shvidenko A, Vaganov E, Walker D (2002) Environmental variation, vegetation distribution, carbon dynamics and water/energy exchange at high latitudes. J Veg Sci 13:301-314

McGuire AD, Anderson FG, Christensen TR, Dallimore S, Guo L, Hayes DJ, Heimann M, Lorenson TD, Macdonald RW, Roulet N (2009) Sensitivity of the carbon cycle in the Arctic to climate change. Ecol Monogr 79:523-555

McNamara JP, Kane DL, Hinzman LD (1997) Hydrograph separations in an Arctic watershed using mixing model and graphical techniques. Water Resour Res 33: 1707-1719

McNamara JP, Kane DL, Hobbie JE, Kling GW (2008) Hydrologic and biogeochemical controls on the spatial and temporal patterns of nitrogen and phosphorus in the Kuparuk River, Arctic Alaska. Hydrol Process 22: 3294-3309

Meehl GA, Washington WM, Santer BD, Collins WD, Arblaster JM, Hu A, Lawrence DM, Teng H, Buja LE, Strand WG (2006) Climate change projections for the twenty-first century and climate change commitment in the CCSM3. J Clim 19:2597-2616

Nadelhoffer KJ, Giblin AE, Shaver GR, Laundre JA (1991) Effects of temperature and substrate quality on element mineralization in 6 Arctic soils. Ecology 72:242-253

Peterson BJ, Hobbie JE, Corliss TL (1986) Carbon flow in a tundra stream ecosystem. Can J Fish Aquat Sci 43: 1259-1270

Peterson BJ, Corliss T, Kriet K, Hobbie JE (1992) Nitrogen and phosphorus concentrations and export for the upper Kuparuk River on the North Slope of Alaska in 1980. Hydrobiol 240:61-69

Peterson BJ, Deegan L, Helfrich J, Hobbie JE, Hullar M, Moller B, Ford TE, Hershey A, Hiltner A, Kipphut G, Lock MA, Fiebig DM, McKinley V, Miller MC, Vestal JR, Ventullo R, Volk G (1993) Biological responses for a tundra river to fertilization. Ecology 74:653-672

Peterson BJ, Holmes RM, McClelland JW, Vörösmarty CJ, Lammers RB, Shiklomanov AI, Shiklomanov RB, Rahmstorf S (2002) Increasing river discharge to the Arctic Ocean. Science 298:2171-2173

Petrone KC, Jones JB, Hinzman LD, Boone RD (2006) Seasonal export of carbon, nitrogen, and major solutes from Alaskan catchments with discontinuous permafrost. J Geophys Res 111:G02020. doi:10.1029/2005JG000055

Petrone KC, Hinzman LD, Shibata H, Jones JB, Boone RD (2007) The influence of fire and permafrost on sub-Arctic stream chemistry during storms. Hydrol Process 21: 423-434

Post E et al (2009) Ecological dynamics across the Arctic associated with recent climate change. Science 325 : 1355-1358

Rawlins MA, Ye H, Yang D, Shiklomanov A, McDonald KC (2009) Divergence in seasonal hydrology across northern Eurasia: emerging trends and water cycle linkages. J Geophys Res 114:D18119. doi:10.1029/2009JD011747
Raymond PA, McClelland JW, Holmes RM, Zhulidov AV, Mull K, Peterson BJ, Striegl RG, Aiken GR, Gurtovaya TY (2007) Flux and age of dissolved organic carbon exported to the Arctic Ocean: a carbon isotopic study of the five largest Arctic rivers. Global Biogeochem Cycles 21:GB4011. doi:10.1029/2007GB002934

Rember RD, Trefry JH (2004) Increased concentrations of dissolved trace metals and organic carbon during snowmelt in rivers of the Alaskan Arctic. Geochim Cosmochim Acta 68:477-489

Rouse WR, Douglas MSV, Hecky RE, Hershey AE, Kling GW, Lesack L, Marsh P, McDonald M, Nicholson BJ, Roulet NT, Smol JP (1997) Effects of climate change on the freshwaters of Arctic and Subarctic North America. Hydrol Process 11:873-902

Sauer VB, Meyer RW (1992) Determination of error in individual discharge measurements. US Geological Survey Open-File Report 92-144

Schimel JP, Bilbrough C, Welker JM (2004) Increased snow depth affects microbial activity and nitrogen mineralization in two Arctic tundra communities. Soil Biol Biochem 36:217-227

Shaver GR, Billings WD, Chapin FS III, Giblin AE, Nadelhoffer KJ, Oechel WC, Rastetter EB (1992) Global change and the carbon balance of Arctic ecosystems. Bioscience 42:433-441

Shaver GR, Johnson LC, Cades DH, Murray G, Laundre JA, Rastetter EB, Nadelhoffer KJ, Giblin AE (1998) Biomass and $\mathrm{CO}_{2}$ flux in wet sedge tundras: response to nutrients, temperature, and light. Ecol Monogr 68:75-97

Shaver GR, Giblin AE, Nadelhoffer KJ, Thieler KK, Downs MR, Laundre JA, Rastetter EB (2006) Carbon turnover in Alaskan tundra soils: effects of organic matter quality, temperature, moisture, and fertilizer. J Ecol 94:740-753

Slavik K, Peterson BJ, Deegan LA, Bowden WB, Hershey AE, Hobbie JE (2004) Long-term responses of the Kuparuk River ecosystem to phosphorus fertilization. Ecology 85:939-954

Steiglitz M, Giblin A, Hobbie J, Williams M, Kling G (2000) Simulating the effects of climate change and climate variability on carbon dynamics in Arctic tundra. Global Biogeochem Cycles 14:1123-1136

Steiglitz M, Shaman J, McNamara J, Engel V, Shanley J, Kling GW (2003) An approach to understanding hydrologic connectivity on the hillslope and the implications for nutrient transport. Global Biogeochem Cycles 17:1105. doi: 10.1029/2003GB002041

Strickland JDH, Parsons TR (1972) A practical handbook of seawater analysis. Fisheries Research Board of Canada, Ottawa, p 310

Striegl RG, Aiken GR, Dornblaser MM, Raymond PA, Wickland KP (2005) A decrease in discharge-normalized DOC export by the Yukon River during summer through autumn. Geophys Res Lett 32:L21413. doi:10.1029/2005 GL024413

Striegl RG, Dornblaser MM, Aiken GR, Wickland KP, Raymond PA (2007) Carbon export and cycling by the Yukon, Tanana, and Porcupine rivers, Alaska 2001-2005. Water Resour Res 43:W02411. doi:10.1029/2006WR00 5201 
Waddington JM, Roulet NT (1997) Groundwater flow and dissolved carbon movement in a boreal peatland. J Hydrol 191:122-138

Wetzel RG, Hatcher PG, Bianchi TS (1995) Natural photolysis by ultraviolet irradiance of recalcitrant organic matter to simple substrates for rapid bacterial metabolism. Limnol Oceanogr 40:1369-1380

White D, Hinzman L, Alessa L, Cassano J, Chambers M, Falkner K, Frances J, Gutkowski WJ Jr, Holland M, Holmes RM, Huntington H, Kane D, Kliskey A, Lee C, McClelland J, Peterson B, Rupp TS, Straneo F, Steele M,
Woodgate R, Yang D, Yoshikawa K, Zhang T (2007) The Arctic freshwater system: changes and impacts. J Geophys Res 112:G04S54. doi:10.1029/2006JG000353

Wollheim WM, Peterson BJ, Deegan LA, Hobbie JE, Hooker B, Bowden WB, Edwardson KJ, Arscott DB, Hershey AE, Finlay J (2001) Influence of stream size on ammonium and suspended particulate nitrogen processing. Limnol Oceanogr 46:1-13

Zar JH (1999) Biostatistical analysis, 4th edn. Prentice Hall, Upper Saddle River, New Jersey, p 929 pp 